\title{
EchoGéo
}

$32 \mid 2015$

Inde : le grand écart spatial

\section{Poverty and inequality in rural India}

Reflections based on two agrarian system analyses in the state of Gujarat

Claire Aubron, Hugo Lehoux et Corentin Lucas

\section{(2) OpenEdition}

Journals

Édition électronique

URL : https://journals.openedition.org/echogeo/14300

DOI : $10.4000 /$ echogeo. 14300

ISSN : 1963-1197

Éditeur

Pôle de recherche pour l'organisation et la diffusion de l'information géographique (CNRS UMR 8586)

Référence électronique

Claire Aubron, Hugo Lehoux et Corentin Lucas, «Poverty and inequality in rural India », EchoGéo [En ligne], 32 | 2015, mis en ligne le 15 juillet 2015, consulté le 10 août 2021. URL : http://

journals.openedition.org/echogeo/14300; DOI : https://doi.org/10.4000/echogeo.14300

Ce document a été généré automatiquement le 10 août 2021.

EchoGéo est mis à disposition selon les termes de la licence Creative Commons Attribution - Pas d'Utilisation Commerciale - Pas de Modification 4.0 International (CC BY-NC-ND) 


\section{Poverty and inequality in rural India}

Reflections based on two agrarian system analyses in the state of Gujarat Claire Aubron, Hugo Lehoux et Corentin Lucas

\section{Introduction}

1 Although the poverty of India's slums and urban areas is evident to any observer, statistical data ${ }^{1}$ shows that most of the sub-continent's poor live in rural areas: $70 \%$ of Indians, and more or less as many of India's poor, live in rural areas (Himanshu et al., 2013; Planning commission, 2014). Agriculture, which constitutes the main activity of $60 \%$ of the active population in rural areas (Himanshu et al., 2013), is indissociable from this rural poverty and hence from the India's spatial divide (Shah, 2002; Landy, 2010). It is sometimes described as a residual activity, which is abandoned by the richest, and no longer involves the masses of rural workers of the past (Gupta, 2005). In a context of low growth in the agricultural sector, as compared with the rest of the economy since the 1990's (Himanshu, 2008), non-agricultural jobs occupied by people living in rural areas are the object of increasing attention and give rise to renewed hopes of moving out of poverty (Nayyar and Sharma, 2005). It is true that all over India the numbers of these non-agricultural jobs are on the increase and studies show that their development has led to a decrease in poverty in the zones studied but this is nonetheless accompanied by a reinforcement of inequality (Himanshu et al., 2013).

2 All these questions that are often addressed at a national level, need to be studied at a local level in order to allow factors and processes that remain invisible at other levels of study to emerge. This article is a contribution to this goal, through the analysis of two agrarian systems in Gujarat. The state of Gujarat, located in the north-west of India has seen high economic growth over the last two decades (Bagchi et al., 2005; Dixit, 2009), and this has often led to its being held up as a model capable of inspiring the rest of India. Gujarat has several major industrial centres and is equipped with a good transport system infrastructure. This growth has occurred in the secondary and 
tertiary sectors as well as in agriculture ${ }^{2}-$ a phenomenon that is less common in contemporary India (Shah et al., 2009). An analysis of the agrarian systems and the relationship between agriculture and rural poverty seems particularly pertinent in this state, which has become a symbol of India's growth. Does rural poverty exist in Gujarat and if so, in what forms? Is it homogenous or do inequalities exist between families living in the countryside? What is it due to? How do non agricultural activities, that a priori, seem to provide numerous opportunities for employment given the economic growth in a variety of sectors, combine with agricultural activities and to what extent do these combinations of activities lead to a redressal of poverty?

Our answers to these questions are based on the results of two fieldworks carried out between April and August 2014 (Lucas, 2014; Lehoux, 2014), using the framework for the analysis of agrarian systems proposed by comparative agriculture (Cochet and Devienne, 2006; Dufumier, 2007; Cochet, 2011). During a first stage, we characterised the biophysical environment on the basis of observations and we reconstructed the agrarian history of the last decades through interviews with older people (20 to 30 people each district); this was completed by the bibliography. This material - a localised spatial understanding of differentiated trajectories of agricultural holdings over the last decades - helped us to develop a first typology of agricultural holdings in each rural taluk $^{3}$. This served as a basis to define a sample that then allowed us to analyse the technical, social and economic functioning of each of these production systems in greater detail, drawing from about sixty interviews with farmers in each taluk. In the end, we modelled the diversity of production systems, by creating archetypes that were each representative of groups of holdings. The figures presented in this article are taken from this modelling process.

\section{A dense fabric of agricultural holdings: genesis and current structure}


Figure 1 - Map of Gujarat and location of the zones studied

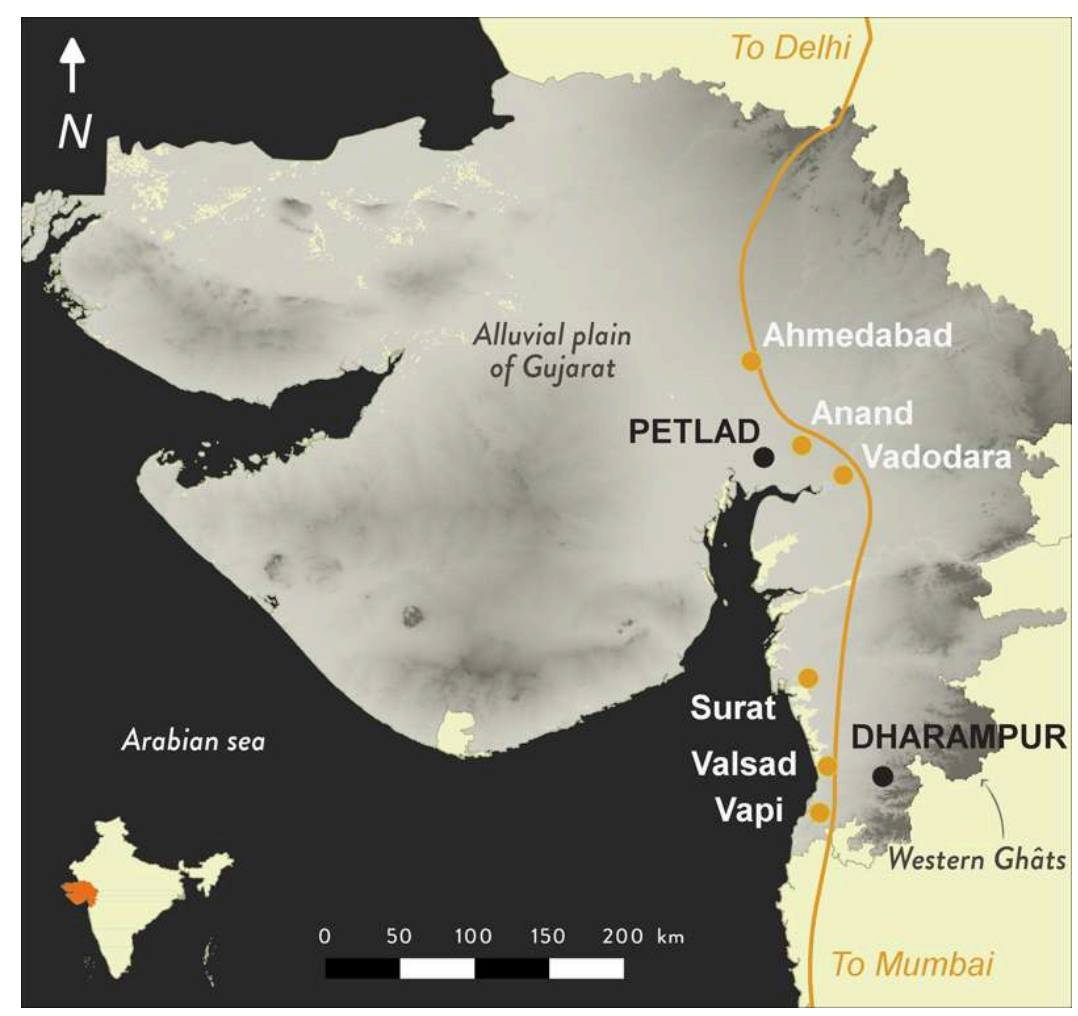

4 The two study zones correspond to two areas of the alluvial plain in Gujarat (see figure 1). Petlad taluk in the north has few topographical variations and corresponds to a plain, which is almost entirely cultivated and irrigated today. Further south, Dharampur taluk is located between an irrigated plain overlooking the Oman Sea to the west, and the mountains adjoining the Deccan plateau (Western Ghats) to the east, with little scope for irrigation. Both these zones receive monsoon rains from June onwards, but Petlad, located quite close to the Kutch desert, which marks Gujarat's northern boundary with Pakistan, receives far less rainfall (800mm annually) than Dharampur $(2500 \mathrm{~mm})$. Today, each of the taluks is organised around a small town; Petlad has a population of 60000 inhabitants and Dharampur 30000 , and both of them are located near the main road and railway axes that connect Delhi to Mumbai. The older industrial centres of Vadodara and Ahmedabad that are experiencing a slowdown in economic growth today are less than $70 \mathrm{~km}$ from Petlad. Dharampur is very close to Surat and Vapi, where industrial activity is expanding rapidly, particularly in the petrochemical sector.

\section{The importance of agriculture in the past}

$5 \quad$ As is typical in north India, for a long time agriculture in Petlad was essentially based on millet, intercropped with legumes, as well as rice cultivated in the lowlands, all during the monsoon period. The castes that controlled the region from the $5^{\text {th }}$ to the $13^{\text {th }}$ centuries (the Solankis, Parmars and Chauhans) seem to have been progressively divested of their power during the Sultanate of Delhi and then the Mughal Empire (Deumari, 2011). The Patels, who were the major beneficiaries of this loss, are believed to have come from Punjab, from where they may have migrated to this part of Gujarat between 500 and 1000. They became tax collectors for the Mughal Empire in the $17^{\text {th }}$ 
century, then for the British crown (Randhawa, 1980) and thus acquired or reinforced landed property rights that spread progressively over the whole area. It is they who first began to cultivate irrigated crops, particularly tobacco, near wells they had dug (Shah et Shah, 1950). In 1950, they thus possessed vast holdings that ranged from 3 to 20 cultivated hectares, worked by farm servants and day labourers who belonged to the rest of the population (the Solanki, Parmar and Chauhan castes, later joined by the Thakors and Vagri, probably as a result of migration). At the time, livestock farming played a major role in renewing the soil fertility of cultivated land and the animals were used for traction when working the land, as well as a means of transport. In 1950, it was the Rabharis, a caste of herders, later joined by the Bharvars, who were responsible for taking the animals out to pasture; they also owned herds of ruminants themselves.

6 For a long time, the only inhabitants of the southern zone (Dharampur) were Adivasis ${ }^{4}$ ("tribals"), who occupied the Indian sub-continent before the arrival of the Aryans. The Adivasis were hunters and gatherers in the forests that made up their environment at the time. They were also familiar with slash and burn techniques and used agroforestry with leaf burning to cultivate rice as well as finger millet, sorghum and millet. It is in the $13^{\text {th }}$ century that a Rajput family from Rajasthan, who fought the Muslims of the Delhi Sultanate, established a small kingdom in Dharampur (Administration of Dharampur, 1921). They collected taxes for the Mughals then the British, but continued to function in a relatively autonomous manner until India's independence. In exchange for services rendered, the king's family distributed land in the plains to Rajput relatives as well as to Parsi, Soni and Patel Brahman families, creating properties that ranged from 20 to 100 ha. After clearing, these lands were used for rice and legume cultivation every year during the monsoon. Most of the labour for these properties in the plains was provided by Adivasis, farm servants or sharecroppers ${ }^{5}$, while the others cultivated monsoon crops for themselves in the mountains. In the plains, livestock farming played the same crucial role as in Petlad and in both areas soil fertility was maintained by a caste of herders, the Ahirs, who raised large herds of cattle and goats.

\section{Agrarian reform, green and white revolutions}

$7 \quad$ As in other regions in India, the laws regulating the agrarian revolution in the years following independence changed the distribution of land in both these taluks, without however, bringing about a total transformation. The absence of a real political will, particularly in the states where the local landed elite were allies, and the exemptions written into the law, or enabled by the ambiguity of the texts, explain the fact that the process of the Indian agrarian reform remained incomplete (Appu, 1997; Pouchepadass, 2006; Breman, 2007a). In Petlad, some of the Solankis, Parmars, Chauhans and Thakors who worked on the Patel's properties gained access to small plots of land, one or two hectares in size, and joined the limited group of small owners that already existed in the region. It was nonetheless the least fertile land that was redistributed in this manner. The areas involved, which were small to start with, grew even smaller due to later land transactions. In fact, some of the beneficiaries of the agrarian reform handed over the land they had received to the Patels, either by voluntary sales, or in the context of lease agreements against loans, which they never managed to pay back. This system of transfer of land rights due to debt, which Servet (2007) describes in its 
temporary form, still exists today. Essentially, however the majority of agricultural workers and herders did not benefit from the agrarian reform and remained landless.

In Dharampur, most of the large land holdings in the plains, which had been granted by the king in the past, were diminished, but some of them remained unaffected. Certain Adivasi workers and Ahir goat farmers gained access to land, either directly, or by purchasing it after the agrarian reform, creating family holdings of between 0,5 to 4 ha in the plains. The other Adivasis became formal owners of the land they cultivated in the mountains. Thus, unlike Petlad, Dharampur does not have a large population of landless farmers. The other transforming factor in the structure of landholdings in these two zones is the division of landed property between the sons ${ }^{6}$, in every generation.

From the 1970's onwards, the green revolution and its three ingredients - irrigation ${ }^{7}$, chemical fertiliser and high yield varieties - (Dorin and Landy, 2002) transformed agriculture in the plains in both these taluks. In the Petlad taluk there are generally two or sometimes even three crop cycles a year on the plots. The cropping systems were reorganised around tobacco, a labour intensive but very profitable irrigated winter crop. In the Dharampur plains, the annual double cropping pattern of rice/ sorghum is the norm in small and medium size farms. The larger farms have adopted less labour intensive and more profitable crops: sugar cane, and from the 1990's onwards, mango orchards. The very small farms (less than 1ha) that resulted from successive divisions, developed vegetable crops in the 2000's, and their products are sought after on the emerging market in the small town of Dharampur. With the development of milk collection and the provision of low cost breeding inputs (artificial insemination, concentrate feed) by the milk cooperatives connected to $\mathrm{AMUL}^{8}$, almost all the farmers in the plains, in both zones have become dairy farmers, including those who were landless. Some Patel landowners in Petlad and some of the former Ahir goat farmers in Dharampur have invested in larger dairy farms, with herds of 30 to 200 dairy cows. Although we will not develop this point here, we should note that these transformations raise environmental questions, both at a local (quantity and quality of water) and global level (consumption of fossil energy, greenhouse gas emissions).

Due to the limited irrigation possibilities, the Adivasis farmers of Dharampur mountains have not been a part of the white and green revolutions. In order to provide for the needs of a growing population, they have extended their monsoon cultivation zones to the area near their houses (rice and legumes) as well as further into the forest (finger millet). The government that seems to have contributed to deforestation by timber extraction, later went on to define reforestation areas where agricultural activity is theoretically banned. Deforestation reduced the biomass produced in the forests, which until then had played a key role in renewing the soil fertility of the cultivated land. This may be related to the reduction in productivity described by the farmers and the low figures we noted during our observations and surveys ( 0,5 to $1,2 \mathrm{t}$ / ha for rice cultivated in the mountains as compared to 2 to $3,5 \mathrm{t} /$ ha in the neighbouring plains). We should note that some Adivasi families in the mountains were able to gain access to irrigation, by installing pumps in the rivers and they have also developed vegetables crops. These investments were encouraged by loans and subsidies for equipment, granted by government programmes targeting tribal populations. 
Table 1 - Characteristics of production systems in the Petlad zone

\begin{tabular}{|c|c|c|c|c|}
\hline Type & Labour force & $\begin{array}{l}\text { Area } \\
\text { (ha) }\end{array}$ & $\begin{array}{l}\text { Cropping } \\
\text { systems }\end{array}$ & $\begin{array}{l}\text { Livestock farming } \\
\text { systems }\end{array}$ \\
\hline $\begin{array}{l}\text { Owners giving their } \\
\text { land in sharecropping }\end{array}$ & Sharecroppers & $0,2-9$ & $\begin{array}{l}\text { Tobacco/ } \\
\text { millet; } \\
\text { Tobacco; } \\
\text { Toba.// } \\
\text { banana; Toba./ } \\
\text { rice }\end{array}$ & $\begin{array}{l}0-1 \quad \text { cross-breed } \\
\text { Holstein or Jersey }\end{array}$ \\
\hline Owners milk producers & $\begin{array}{l}\text { Family (and } \\
\text { permanent } \\
\text { employees) }\end{array}$ & $0,9-2$ & $\begin{array}{l}\text { Lucerne/ } \\
\text { sorghum; } \\
\text { Maize/ } \\
\text { sorghum }\end{array}$ & $\begin{array}{l}12-50 \text { cross-breed } \\
\text { cows }\end{array}$ \\
\hline $\begin{array}{l}\text { Owners with } \\
\text { diversified productions }\end{array}$ & $\begin{array}{l}\text { Family and day } \\
\text { labourers }\end{array}$ & $0,4-2$ & $\begin{array}{l}\text { Tobacco/rice; } \\
\text { Toba./mil.; } \\
\text { Elephant grass }\end{array}$ & $\begin{array}{l}\text { 4-12 cross-breed } \\
\text { cows }\end{array}$ \\
\hline Small owners & $\begin{array}{l}\text { Family and day } \\
\text { labourers }\end{array}$ & $0,1-0,36$ & $\begin{array}{l}\text { Tobacco/rice; } \\
\text { Tobacco/ } \\
\text { millet }\end{array}$ & 1-2 she-buffaloes \\
\hline Sharecroppers & $\begin{array}{l}\text { Family and day } \\
\text { labourers }\end{array}$ & $\begin{array}{l}0 \quad(0,5-3 \quad \text { in } \\
\text { sharecrop. })\end{array}$ & $\begin{array}{l}\text { Tobacco/ } \\
\text { millet; } \\
\text { Tobacco; } \\
\text { Toba.// } \\
\text { banana; Toba./ } \\
\text { rice }\end{array}$ & 0-2 she-buffaloes \\
\hline Day labourers & Family & 0 & - & $0-1$ she-buffalo \\
\hline Pastoral farmers & Family & 0 & - & $\begin{array}{l}5-25 \text { buffaloes } \\
\text { and local breed } \\
\text { cattle }\end{array}$ \\
\hline
\end{tabular}

According to the 2011 census data, in the district of Anand, which the Petlad taluk belongs to, there are 287000 "agricultural workers" (that include both our categories, sharecroppers and day labourers) and 204000 "cultivators" (people who own or lease land and work over 6 months a year in agriculture).

Table 2 - Characteristics of production systems in the Dharampur zone

\begin{tabular}{|l|l|l|l|l|l|}
\hline Type & Labour force & $\begin{array}{l}\text { Area } \\
\text { (ha) }\end{array}$ & $\begin{array}{l}\text { Access } \\
\text { to water }\end{array}$ & Cropping systems & $\begin{array}{l}\text { Livestock } \\
\text { farming } \\
\text { systems }\end{array}$ \\
\hline
\end{tabular}




\begin{tabular}{|c|c|c|c|c|c|}
\hline Mango producers & $\begin{array}{l}\text { Permanent and } \\
\text { temp. employees }\end{array}$ & $4-40$ & Yes & $\begin{array}{l}\text { Irrigated mango } \\
\text { orchards; } \\
\text { Teak }\end{array}$ & - \\
\hline $\begin{array}{l}\text { Pluri-active } \\
\text { farmers with } \\
\text { sugarcane }\end{array}$ & $\begin{array}{l}\text { Family and } \\
\text { temp. employees }\end{array}$ & $<4$ & Yes & $\begin{array}{l}\text { Sugarcane }_{2} / / \text { rice; } \\
\text { Irrigated mango } \\
\text { orchards }\end{array}$ & - \\
\hline Milk producers & $\begin{array}{l}\text { Family and } \\
\text { perman. } \\
\text { employees }\end{array}$ & $<4$ & Yes & $\begin{array}{l}\text { Rice/sorghum; } \\
\text { Non irrigated mango } \\
\text { trees }\end{array}$ & $\begin{array}{l}15-100 \text { she- } \\
\text { buffaloes or } \mathrm{CB} \\
\text { cows }\end{array}$ \\
\hline $\begin{array}{ll}\text { Farmers } & \text { with } \\
\text { diversified } & \\
\text { productions } & \end{array}$ & Family & $<4$ & Yes & $\begin{array}{ll}\text { Rice/sorgh.; } & \text { Sugarc }_{2} / / \\
\text { rice; Non } & \text { irrigated } \\
\text { mango trees } & \end{array}$ & $\begin{array}{l}1-5 \text { she- } \\
\text { buffaloes or } \mathrm{CB} \\
\text { cows }\end{array}$ \\
\hline Vegetable growers & $\begin{array}{l}\text { Family and } \\
\text { perman. } \\
\text { employees }\end{array}$ & $<1$ & Yes & Various vegetables & - \\
\hline Pastoral farmers & Family & $<2$ & No & $\begin{array}{l}\text { Rice; } \\
\text { Legumes }\end{array}$ & $20-100$ goats \\
\hline $\begin{array}{l}\text { Farmers with } \\
\text { rainfed crops }\end{array}$ & Family & $<2$ & No & $\begin{array}{l}\text { Rice; Legumes; } \\
\text { Finger millet }\end{array}$ & $\begin{array}{l}0-2 \text { local breed } \\
\text { cattle }\end{array}$ \\
\hline
\end{tabular}

We estimate that in the taluk there are 15 families specialising in mango production and 30 to 40 families specialising in dairy farming. In 2008, the Gujarat government listed 165662 Adivasis or Scheduled Tribes in Dharampur taluk, that is to say $91 \%$ of the population (Patel, 2011). The majority of them are probably involved in agricultural activities - $84 \%$ of the taluk's active population works in agriculture, according to the 2011 census -, but all of them are not "farmers with rainfed crops".

\section{A myriad of farms connected by workforce flows}

Because of their small size and their almost continuous occupation of the space in the irrigated plains, farms make up a particularly dense fabric in both the districts. This density, which is related to the land structure, goes hand in hand with a "social" density generated by the flows of the workforce between farms. Almost all the owners in the irrigated zone - mango producers, pluri-active farmers with sugarcane, milk producers, vegetable growers in Dharampur as well as families who own over 0,1 ha of land in Petlad - in fact employ labour from outside the family to cultivate all or some of their crops, as well as for livestock farming (see tables 1 and 2). According to our calculations, this external workforce carries out up to $95 \%$ of the work in certain farm holding categories and this provides an indication of the failure of the agrarian reform, which was intended to give the land to those who worked it. The workforce consists of sharecroppers 9 (for the crops in Petlad), day labourers (for crops in both taluks), seasonal employees or piece wage workers (for the crops in Dharampur) or permanent employees (for livestock farming in both taluks). These workers may or may not own land, which they cultivate for their own benefit: this is the case of certain sharecroppers in Petlad who received land during the agrarian reform, as well as of Adivasi farmers in the Dharampur mountains, who come to transplant rice or harvest 
mangos in the plains. In a certain number of cases, these workers also raise dairy animals for their own benefit, for their own consumption, and for sale. There can be a combination of different types of workers on a farm; the owner takes them on depending on the jobs that need doing. In Petlad, sharecroppers usually employ day labourers for the tobacco harvest.

In addition to these workforce flows, there also exist temporary land right transfers between farms. In addition to the sharecropping already discussed in Petlad, land is also rented out; this trend has increased with the rise in international migration in some Patel families from the 1970's onwards: the absentee owners who live in the United States, the United kingdom, or in Canada, rent their land to relatives, who then generally employ sharecroppers or employees to work the land. In Petlad, the relationship to land and the social division of labour thus reveals a four-tier system involving the absentee owner, the owner who is present, who entrusts the land to sharecroppers, the sharecroppers and the day labourers employed by the sharecroppers. Figure 4 shows a comparison of each of these social categories' contribution to the work and the share of added value each one receives.

\section{Poverty of the majority and the landowners' economic power}

\section{Landless farmers and farmers with no water face extreme poverty}

13 Figures 2 and 3 show the income generated by agriculture according to the production system. Let us first look at the lower part of the graph that corresponds to social categories that are far from negligible in terms of their numbers. In both the zones, in fact, we estimate that at least $30 \%$ of families make an income ${ }^{10}$ from agriculture that is lower than the recently redefined national poverty threshold (32 rupees or $0,41 €$ / person/day at the time of the study, according to the Planning Commission, 2014 ${ }^{11}$ ) (see figures 2 and 3). While this result is not surprising for Dharampur taluk, an area considered poor because it is a "tribal" area, this was not the case in Petlad taluk. Although it is densely populated, the Petlad zone is a fertile plain where the green and white revolutions (the latter was born here, before spreading to the rest of India) have led to important agricultural growth. In Petlad it is access to land ownership, and in Dharampur, access to irrigation water that determine the capacity to obtain an agricultural income above the national poverty threshold (see figures 2 and 3). Here we find an observation that has long been established in rural India, where the poorest are invariably those who have no land or no water to irrigate it (Shah, 2005; Pouchepadass, 2006), but the number of households in this position is extremely high, particularly for a state that has been held up as a model of progress.

The situation is all the more disturbing as some of the current transformations contribute to a further deterioration. If it is proven, the soil fertility crisis affecting mountain agriculture in the Dharampur mountains will thus decrease the agricultural income of the Adivasi families who only have their rain fed crops. It will be all the more difficult for them to resolve the problem as they do not have the means to buy fertilizers and they use a part of the animal waste as a fuel for cooking and their rice straw to pay for milling the grain. This suggests that access to biomass can be just as crucial as access to agricultural land: while it is difficult to live off agriculture with land 
and no water in a number of regions in India, what happens when in addition, the population does not have the means to renew the soil fertility?

In the case of the smallest landholdings, the division of land between the sons, when property is passed on, is another factor that leads to the pauperisation of farmers. This process is going on at Indian level (Dorin et al., 2013) as well as in the two zones studied. It pushes small landowners into the category of micro landholders, with a lower agricultural income, except when they manage to develop vegetable crops or dairy farming. Some have managed to do this successfully in both the taluks, but this presupposes being in possession of irrigable land. Loans or subsidies granted by the milk cooperatives and the state for the acquisition of irrigation equipment and livestock, also seem to play a determining role in these trajectories. When the size of the landholding would be reduced to under 0,08 ha per son, families in Petlad do not divide up the land: they pass it on to just one son, leaving the others to join the ranks of the landless. Finally, the decrease of water resources and the increased cost of accessing water due to the falling level of the water table, contribute to pushing farmers who have access to irrigation into the category of farmers without water. This process, which we observed in Dharampur, is occurring in certain Indian regions as well (Shah, 2009), and has been described in the north of Gujarat (Barry and Issoufaly, 2006). It contributes to reinforcing inequalities as only the richest owners can invest in ever-deeper bore wells.

Figure 2 - Annual agricultural income by production system in the Petlad zone

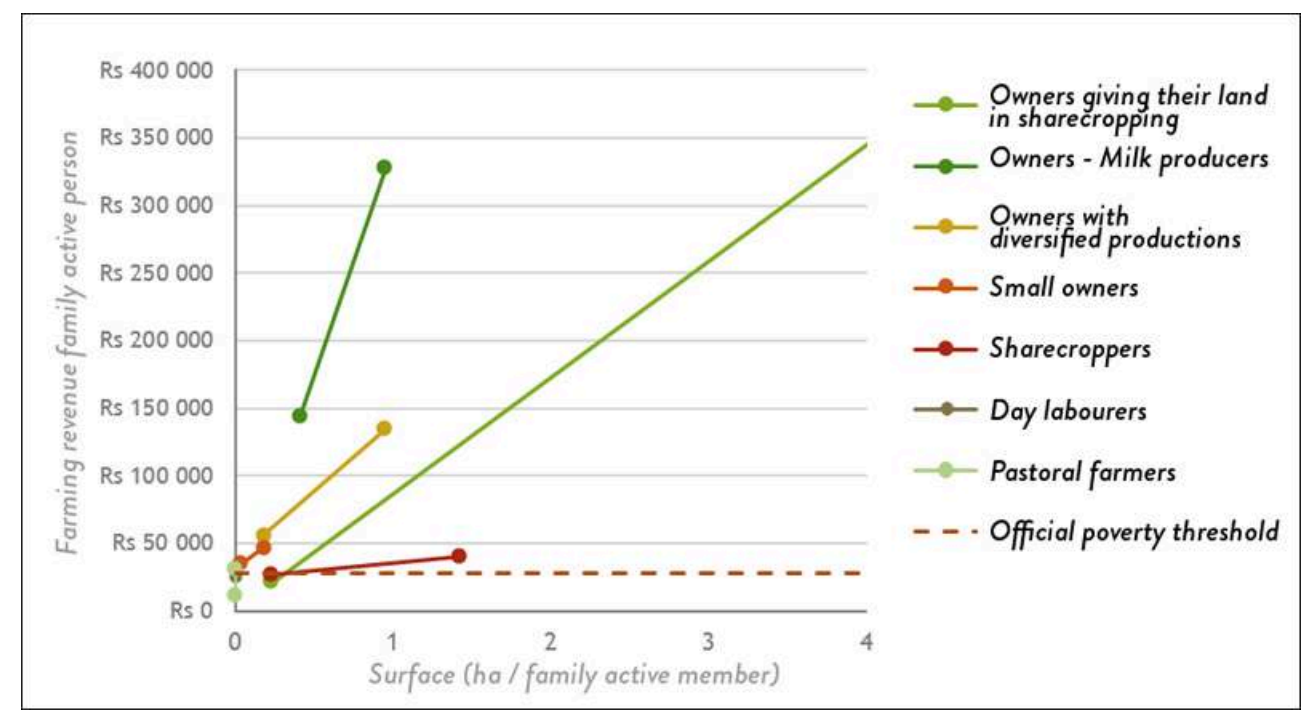


Figure 3 - Annual agricultural income by production system in the Dharampur zone

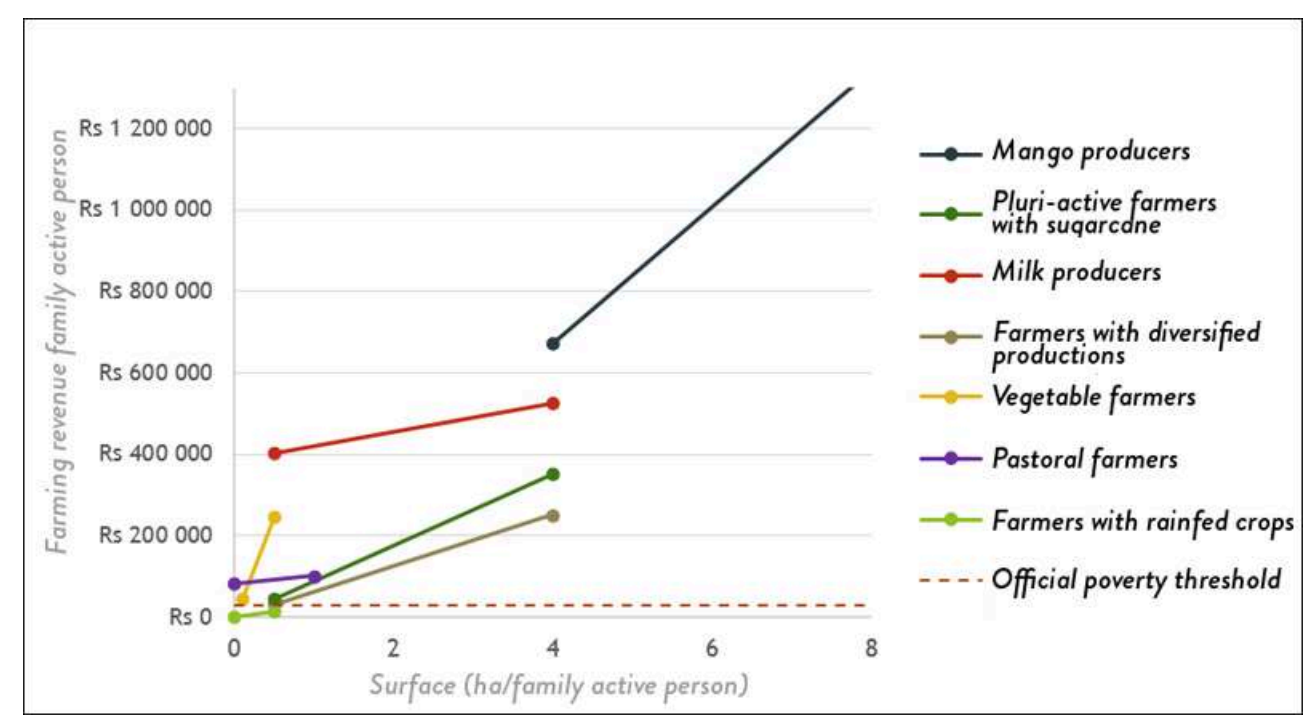

\section{Social relations and unequal distribution of added value}

The poverty experienced by some of the farmers in both these taluks however, is not only a structural problem related to the low availability of resources in terms of land, water or even biomass per family. It is also linked to the existing social relations and the manner in which added value is redistributed between owners, sharecroppers or labourers. Although our observations on this subject were limited and would be worth completing, it clearly seems that over the last two decades a certain emancipation of the most disadvantaged social categories has taken place, just as it has been described in other parts of rural India (Hariss et al.; Jodhka, 2014). Thanks to the fragmentation of large agricultural landholdings, the departure of a section of the owners (Breman 2007b), the quota system for castes in higher education and the civil services, the growing political influence in the hands of certain categories of farmers (Pouchepadass, 2006; Jaffrelot, 2006; Jodhka, 2014), subsidies for equipment made available to the poorest, or their involvement in non agricultural activities, some of the families in both the zones studied, have become less socially dependent on the landowners. Some of the landless youth in Petlad thus choose not to take land as sharecroppers, even though they could, in order to freely enjoy the opportunities available to them on the daily wage market.

Nonetheless, the relationships between owners and employees or sharecroppers are far from balanced. This is evident from the perpetuation of the lease against loans system in Petlad, that dispossesses farmers of their lands; the shoddy housing for the Adivasi workers who come to the plains for a few weeks, or even the child labour in the mango orchards. Above all, the added value agriculture produces is very unequally shared. An estimation of the daily productivity of labour ${ }^{12}$ in the different land utilisation systems, is highly informative in this respect: if we exclude from the analysis monsoon crop farming in the Dharampur mountains, characterised by very low labour productivity, we see that the remuneration for day labourers (between 100 and 150 Rs, ie between 1,20 to $2 €$ /day when the study was carried out) only corresponds, at the most, to half the wealth created for a days work. In some cropping systems that include tobacco or 
chillies, in Petlad, or in the case of the mango orchards in Dharampur, the daily wage only represents a third or a fifth of the added value, while the rest goes to the owner ${ }^{13}$.

Figure 4 - Contribution in terms of work and distribution of the net added value in the OwnersSharecroppers-Day labourers system in Petlad

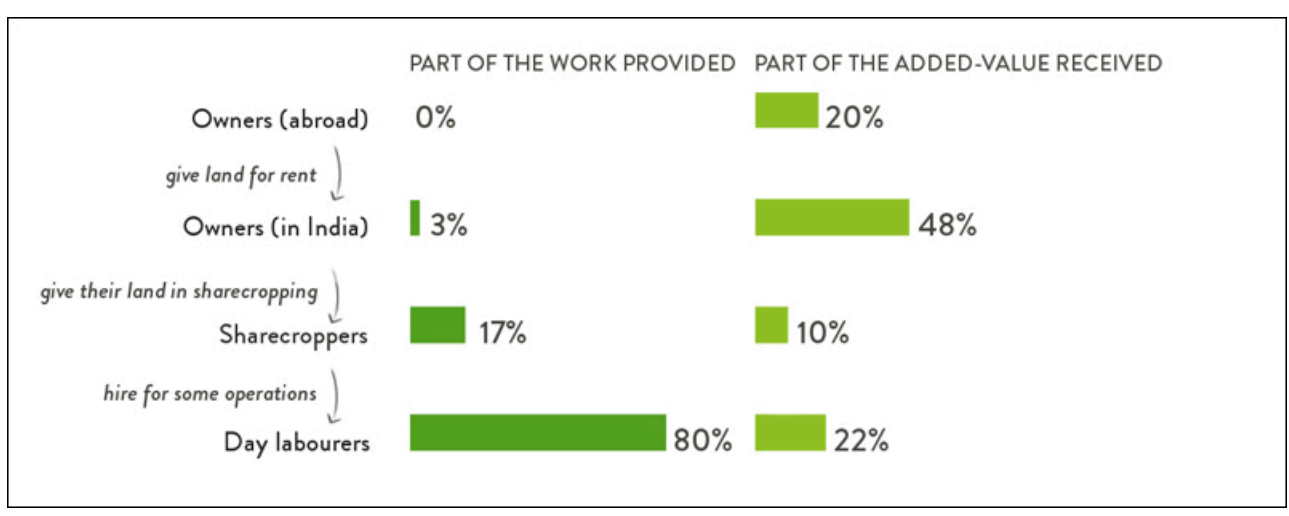

Under the present conditions, the sharecropping agreements in Petlad seem to be more advantageous for the workers than daily labour: in the system described in figure 4, the difference between the sharecroppers' contribution to the work (17\%) and the proportion of added value they receive $(10 \%)$ is lower than that of day labourers (who provide $80 \%$ of the work and receive $22 \%$ of the added value). The sharecropping agreements are all the more attractive as they often include other advantages, which are not represented in the calculations, such as loans granted by the owner to cover health costs or a daughter's marriage, or even the sharecropper's right to cultivate fodder along the edges of the fields. These advantages are granted in the context of the relationship between the owners' and the sharecroppers' families, which usually go back several generations. Being a sharecropper is not only a question of choice: the Vagri caste, for example finds it difficult to access this status and members of this caste are often limited to working as day labourers. Although the role of loans in these relationships would need to be analysed in greater detail, they are, to some extent, reminiscent of certain ancient forms of patronage and bonded labour that existed in rural India (Pouchepadass, 2005; Breman, 2007a; Breman and Guérin, 2009). To complete this comparison between sharecroppers and day labourers, we should note that sharecropping involves greater risks and unlike daily labour, does not provide immediate access to an income. Whether it be in the context of daily labour or sharecropping, whatever happens, the owners receive between half and four fifths of the added value for the crops, although the work they provide is often minimal (see figure 4). In both the zones studied, poverty is thus indissociable, not only from the unequal distribution of land and water, but also of the added value. This confirms the results of research carried out in other regions of India, highlighting the very low payment for work under different land rental, sharecropping or salaried agricultural employment agreements that were the object of these studies (Rawal, 2006; Ramachandran et al., 2010).

\section{The landowners' economic power}

19 While the owners are no longer the only authorities, and today a part of social life is beyond their control, their economic power - with an income from agriculture 10 to 40 
times higher than that of the poorest and which can be as high as 1.2 million rupees ${ }^{14}$ yearly for some mango producers in Dharampur (see figures 2 and 3) - endows them with an important and influential role in what concerns the future of both these zones. The richest amongst them are usually involved in non-agricultural activities locally, elsewhere in the state or abroad. The proportion of their income derived from agriculture may have become minimal, but this in no way encourages them to let go of their land. They have it cultivated through a variety of systems, which involve a varying number of intermediaries, with as we mentioned above, a very favourable share of the added value. As we can see from Brennan's analyses (2007b), carried out in other parts of Gujarat it is effectively this unequal distribution of land, water and added value that allowed and still allows those who have retained large enough landholdings, to increase their capital by making various investments. These investments concern agriculture (irrigation infrastructure, specifically bore wells which are deeper and deeper in Dharampur and hence increasingly expensive; creation of mango orchards), non agricultural activities (businesses in Petlad), encouraging their children to pursue higher education which then gives them access to well paid, non-agricultural jobs or international migration from Petlad.

At the other end of the social scale, day labourers and sharecroppers in Petlad and Adivasis in the Dharampur mountains, are totally dependent on landowners to access agricultural jobs, which are vital for them. In this respect, the owners' choice of crops and methods of cultivation are crucial. From the 1970's onwards, the development of tobacco cultivation and the multiplication of crop cycles with the extension of irrigation in the Petlad zone, led to a large demand for workers, despite the rise in motomechanisation for ploughing. This made it possible to absorb the demographic growth of sharecroppers and day labourers, without, however, taking them out of poverty. Some owners in Petlad today choose to have only one crop cycle a year, tobacco, or to replace tobacco with eucalyptus plantations. In Petlad, large dairy farms with over 100 cows are closing down. In Dharampur, mango orchards are replacing rice and sugar cane in the largest properties. As several authors have observed (Gadgil and Guha, 1993; Breman, 2007a), all these changes decrease the demand for agricultural labour - and in some cases accentuate the seasonality of the work - with a huge impact on the poorest. The motivation of the landowners is the high market price for these products (tobacco, mangos) and the rise in costs. One of the things they often say is that the local daily agricultural wage is rising and this is their justification for the acquisition of motomechanised equipment that decreases the need for labour. Another response is the use of a workforce from other regions in India that is probably even poorer and hence willing to work for even lower salaries. The agricultural workers employed in the large dairy farms in Petlad, as well as a section of the mango harvesters in Dharampur, are thus migrants from Uttar Pradesh and Bihar ${ }^{15}$. The offer of agricultural work is hence shaped by the choices made by landowners in both zones, as it is ultimately in their hands that agricultural development rests.

\section{Non-agricultural activities that do not change the contours of inequality}

Whether it be at the top or the bottom of the social ladder, there are a large number of farmers in both the regions studied who are involved in non-agricultural activities. 
Only farmers who have land holdings that function mainly with a family workforce, who own a minimum of land and have access to water, specialise in agriculture. This is also the case of some farmers who have a lower agricultural income, but who are older and hence have fewer needs. As in other regions of India (Abraham, 2009; Himanshu et al., 2013), these non-agricultural activities seem to have gained momentum in the two taluks over the last decades, particularly for the poorest. Families grasp the opportunities represented by the increase in jobs related to industrialisation and urbanisation and service development, particularly in small towns.

It is clear that this represents a factor of social change (Gupta, 2005; Jodhka, 2014): these families are no longer totally dependent on the landowners, some members of the families travel frequently, discover towns, contribute to defining its codes, work in new sectors, etc. Combined with the setting up of public actions - food distribution programmes, electrification, improvement of the road network, development of infrastructure and health services - this increase in non-agricultural activities creates the image of an improvement in living conditions, a "modernisation" of society. What is the situation in the two taluks studied? Do non-agricultural activities make it possible to redress poverty and to reduce inequality? Are we witnessing an abandon of agriculture by the poorest and a shift of the workforce from agriculture to other sectors of the economy?

\section{Differentiated non-agricultural activities}

The term non agricultural activity covers a wide variety of activities. Those implemented in both the taluks can be classified in the following manner, by order of globally increasing annual remuneration: (i) temporary salaried activity (daily labour or continuous employment for several weeks) physically demanding (manual labour, wood cutting, bricklaying, various building sites, cleaning, industrial labour); (ii) unqualified salaried employment (salesperson, in charge of cleaning, watchman, waiter, etc.); (iii) school teacher; (iv) small commercial activity, self employed; (v) permanent qualified employee (bank employee, health services, cooperatives, veterinary services, industry, administration, headmaster of a school); (vi) entrepreneurship with large investments (restaurant, real estate, local industry, rental of agricultural equipment, sawmill).

These non agricultural are not implemented randomly within the populations studied. As it has been shown in other works (Thorat et al., 2005; Rawal, 2006; Breman 2007b; Abraham, 2009) it appears that the type of non agricultural employment rural workers in both the zones have access to, is closely linked to their social origin and hence the type of farm they come from. In Petlad, some Patel owners occupy a qualified salaried job locally or abroad and others often manage various businesses in which they have invested. In Dharampur, the largest owners who are sugar cane and mango producers, generally also have a qualified salaried job in the industrial or tertiary sector in developing towns in the South of Gujarat (Vapi, Surat, Valsad) and some are sawmill owners. In both taluks, in some family landholdings - small landowners in Petlad and farmers with diversified production in Dharampur - one of the family members may occupy a permanent unqualified job, that of school teacher if they have been able to take advantage of the quota system or even have a small commercial activity; they are thus able to diversify their sources of incomes. It in nonetheless extremely rare that 
they are able to access better paid non agricultural jobs, as their investment capacity or level of studies remains $l w^{16}$. Finally, for day labourers and sharecroppers in Petlad, as well as for the farmers with rainfed crops in the Dharampur mountains, it is almost impossible to find jobs apart from daily wage jobs, which are highly physically demanding and badly paid and even during the slow agricultural months they do not manage to find work every day. The father, the older sons and sometimes even the mother, work in the service sector that is developing in small towns (this is the case of the Adivasis in Dharampur), in construction or public works. Because of the cost of transport and housing, it is generally difficult for them to explore the more profitable job markets, that are just as physically demanding, but better paid in places like Vapi, which are further away.

\section{The necessity and fragility of non agricultural jobs for the poorest}

In what concerns the poorest families, non-agricultural activities correspond to a desperate need given the low income derived from agriculture. As we can see from figures 2 and 3, monsoon farmers in Dharampur, day labourers and some of the sharecroppers in Petlad, cannot live from agriculture alone and this is a powerful motivation for them to take up non-agricultural activities of any kind. The total income they obtain by combining agricultural and non agricultural activities, which is close to the official poverty threshold (28000 rupees annually, for the 2.5 people a member of the working population is responsible for) reveals this fragility: a landless livestock farmer in Petlad with a buffalo working as a day labourer, brick laying 14 days a month, can produce a total annual income of 25000 rupees. A farmer involved in rainfed agriculture in the Dharampur mountains, who manages to find 100 days of employment a year as a day labourer outside of his farm, can generate a maximum annual income of $35000 \mathrm{Rs}^{17}$. Thus, the growth of non-agricultural activities does not prove that by this means these families have found a means to improve their condition in a lasting manner. For lack of other alternatives, they may in fact, be forced to accept very poor work conditions and salaries (Breman, 2007a, Harriss-White and Gooptu, 2009).

In both taluks, the forced nature of non-agricultural activities that the poorest of rural dwellers engage in is likely to be reinforced by the current trends. The division of land between generations, the decline in soil fertility in the Dharampur mountains, the increasing scarcity of water resources, the landowners decreasing demand for agricultural labour, the increase in the price of agricultural inputs and the rise in the cost of living, are so many factors that lead to a decline in agricultural income, in real terms, which makes non-agricultural activities indispensable for the poorest.

The fragility of this path out of poverty via non-agricultural employment is corroborated by analyses that have been conducted all over India, which suggest that beyond the question of the salary, the number of these non agricultural jobs is far to low to absorb the mass of rural workers involved in agriculture (Dorin et al., 2013). Economic growth in India, which is certainly strong, (an average of $6,8 \%$ annually between 1993 and 2013), is based mainly on the service sector (67\% of the GDP in 2013) which generally creates less jobs than industry and is supported by a highly capitalistic industrial sector that generates little employment (Kannan and Raveendran, 2009). The diagnosis of this jobless growth led to the creation in 2005 of the right to 100 days of employment annually on public works sites for the poorest, under the Mahatma Gandhi 
National Rural Employment Guarantee Act, but this seems to be little developed as yet in the two taluks studied ${ }^{18}$.

\section{Towards a shift out of agriculture for the poorest?}

Studies carried out in other regions in India highlight the abandon of agricultural activities by some of the poorest (Gupta, 2005; Jodhka, 2014). What is the situation in the zones we studied? This could happen to the day labourers in Petlad, if the demand for agricultural workers was to decrease, with tobacco being replaced by eucalyptus, for example. Some of these day labourers have in fact already ceased livestock farming, as the time they spent collecting fodder along the edges of roads and canals, reduced their availability for daily jobs, both agricultural and non agricultural. With regard to the Adivasis, it would seem that even if they look for work elsewhere, they continue to cultivate pluvial crops on their land in order to have a minimum of rice and legumes to feed their families, and they continue to do this even if they have access to food distributed at low cost under the Public Distribution System. The choices rural families make between agricultural or non-agricultural activities cannot be interpreted merely as a general movement from one towards the other. These activities are often combined in what researchers have now come to call "activity systems" (Dufumier, 2006; Gasselin et al., 2012). The combination is arrived at after due consideration of the local conditions and the family's situation and they define: (i) the importance, the regularity and the security of the agricultural income they can obtain, given their access to land and water, and the manner in which the added value is shared; (ii) the remuneration, the location, the regularity, the security of the non-agricultural employment they can obtain; (iii) the possibilities of spreading the family workforce between the different activities. If the conditions are favourable, certain families may even choose to totally abandon farming to take up non-agricultural activities locally, or via migration. Landless day labourers are probably the most inclined to follow this path, although the landless farmers who have developed livestock farming thanks to the loans provided by milk cooperatives, show a reverse trend in Dharampur. We should however reiterate that it is not because they choose "non-agricultural" occupations that they will necessarily be able to move out of poverty. This could even have the opposite effect given the type of non-agricultural activities exercised by the poorest families in both the zones. Thus, in Petlad, if the owners decide to replace tobacco, a crop that demands intensive labour, by eucalyptus, unless this shift is accompanied by stable and well paid job creation in other sectors of the economy, the "forced" exit of daily labourers working in these tobacco fields will be anything but a solution to poverty.

\section{Conclusion}

In both the zones studied, agriculture does not constitute a residual activity and the families who actually abandon it, are rare. Even if they do not work directly on the land, and in some cases they no longer even live in India, owners keep their land; the families who own very little land - or own land with no water - hold on to it as a form of security and like the landless, combine agricultural and non-agricultural activities. Thus agriculture contributes to the survival of tens of thousands of families in both 
taluks. It also plays a role in India's food security, something that is of great value in a country that will soon be one of the most populated in the world (Landy, 2008).

The research we carried out confirms the extreme poverty that reigns in India's rural zones, in a state that nonetheless shows a high growth level, including in the agricultural sector. It shows how this poverty, in both the zones studied, can be explained through an unequal distribution of land, water as well as added value, that is deeply entrenched in social relations of dependency, the essence of which has finally changed very little over the last decades. However essential non agricultural activity has become, particularly for the poorest, it does not change these inequalities and hence is not a way of redressing poverty. In the light of this work, the perspective that shows India's economic growth spontaneously leading the rural poor forwards in its wake, towards some kind of social advancement, seems highly unrealistic.

Public actions that aim to redress inequality in rural zones, seem more legitimate than ever. Our study suggests that policies for rural development that include the poorest and take their interests into account, represent an efficient means of attaining this goal. In the recent history of both zones, the agrarian reform, access to dairy farming for everyone in the plains via the milk cooperatives, subsidies or loans for irrigation equipment that have permitted certain Adivasi families in Dharampur to develop vegetable crops, have each in their own way, provided means for upwards social mobility for poor rural families. Although they have limitations, which should be analysed, it would certainly be constructive to draw inspiration from these actions in order to define policies that would allow India to benefit more fully from the employment and food resources that agriculture has to offer.

\section{BIBLIOGRAPHIE}

Abraham V., 2009. Employment Growth in rural India: Distress-Driven? Economic and Political Weekly, 44, p. 97-104.

Admnistration of Dharampur, 1921. Administrative history of Dharampur. Dharampur.

Agarwal B., 2005. Landmark Step to Gender Equality. The Hindu, 25 sept 2005.

Agarwal B., 1988. Who sows? Who reaps? Women and land rights in India. The Journal of Peasant Studies, 15, p. 531-581.

Appu P.S., 1997. Land reforms in India: a survey of policy, legislation and implementation. Vikas, New Delhi.

Bagchi A.K., Das P., Chattopadhyay S.K., 2005. Growth and Structural Change in the Economy of Gujarat, 1970-2000. Economic and Political Weekly, 40, p. 3039-3047.

Banerjee P., 2005. Femmes en Inde : législation et réalités. Diogène, 212, p. 107-127.

Barry E., Issoufaly H., 2006. L'agriculture en Inde du Nord, Gujarat : histoire et perspectives. Les Indes Savantes, Paris. 
Breman J., 1974. Patronage and Exploitation: Changing Agrarian Relations in South Gujarat, India. University of California Press, Berkeley and Los Angeles.

Breman J., 2007a. Labour bondage in west India: from past to present. Oxford University Press, New Delhi.

Breman J., 2007b. The poverty regime in village India: half a century of work and life at the bottom of the rural economy in South Gujarat. Oxford University Press, New Delhi, Oxford.

Breman J., Guérin I., 2009. Introduction: on bondage old and new. In Breman J., Guérin I., Prakash A. (ed.), India's Unfree Workforce of Bondage Old and New. Oxford University Press, New Delhi, p. $1-17$.

Cochet H., 2015. Controverses sur l'efficacité économique des agricultures familiales : indicateurs pour une comparaison rigoureuse avec d'autres agricultures. Revue Tiers Monde, 1/2015, p. 9-25.

Cochet H., 2011. L'agriculture comparée. Quae, Versailles.

Cochet H., Devienne S., 2006. Fonctionnement et performances économiques des systèmes de production agricole : une démarche à l'échelle régionale. Cahiers agricultures, 15, p. 578-583.

Denis E., Marius-Gnanou K., 2011. Toward a better appraisal of urbanization in India. Cybergeo : European Journal of Geography, document 569

Deumari M.S., 2011. A dissertation submitted for the degree of master of library, Petlad a study, (Gujarati).

Dixit A.K., 2009. Agriculture in a High Growth state: Case of Gujarat (1960 to 2006). Economic and Political Weekly, 44, p. 64-71.

Dorin B., Hourcade J.-C., Benoit-Cattin M., 2013. A World without Farmers? The Lewis Path Revisited. CIRED Working Paper , 47, 22 p.

Dorin B., Landy F., 2002. Agriculture et alimentation de l'Inde : les vertes années (1947-2001). Éditions Quae, Versailles.

Dufumier M., 2007. Agriculture comparée et développement agricole. Revue Tiers Monde, 2007/3, p. 611-626.

Dufumier M., 2006. Diversité des exploitations agricoles et pluriactivité des agriculteurs dans le Tiers Monde. Cahiers agricultures, 15, p. 584-588.

Dufumier M., 2004. Agricultures et paysanneries des Tiers mondes. Karthala Editions, Paris.

Gadgil M., Guha R., 1993. This fissured land: an ecological history of India. University of California Press, Berkeley and Los Angeles.

Gasselin P., Vaillant M., Bathfield B., 2012. The activity system. A position paper, in: 10th European IFSA Symposium "Producing and Reproducing Farming Systems: New Modes of Organization for the Sustainable Food Systems of Tomorrow". Aarhus.

Guérin I., Roesch M., Venkatasubramanian G., 2007. « Ne nous libérez pas ! ». Autrepart, 43, p. 121-133.

Gupta D., 2005. Whither the Indian Village: Culture and Agriculture in 'Rural' India. Economic and Political Weekly, 40, p. 751-758.

Harriss J., Jeyaranjan J., Nagaraj K., 2012. Rural Urbanism in Tamil Nadu. Notes on a "Slater Village": Gangaikondan, 1916-2012. Review of Agrarian Studies, 2, 2. 
Harriss-White B., Gooptu N., 2009. Mapping India's world of unorganized labour. Socialist Register, 37, p. 89-118.

Himanshu H., 2008. Growth, employment and poverty reduction: post-reform Indian experience. LSE Asia Research Centre Working Papers, 23.

Himanshu H., Lanjouw P., Murgai R., Stern N., 2013. Nonfarm diversification, poverty, economic mobility, and income inequality: a case study in village India. Agricultural Economics, 44, p. 461-473.

Jaffrelot C., 2006. La démocratisation paradoxale du système politique. In Jaffrelot C. (ed.), L'Inde Contemporaine. De 1950 À Nos Jours. Fayard, Paris, p. 80-106.

Jodhka S.S., 2014. Emergent Ruralities. Revisiting Village Life and Agrarian Change in Haryana. Review of rural affairs, Economic and Political Weekly, 49, p. 5-17.

Kannan K.P., Raveendran G., 2009. Growth Sans Employment: A Quarter Century of Jobless Growth in India's Organised Manufacturing. Economic and Political Weekly, 44, p. 80-91.

Kumar M.D., Narayanamoorthy A., Singh O.P., Sivamohan M.V.K., Bassi N., 2014. Unraveling Gujarat's agricultural growth story. In The Water, Energy and Food Security Nexus: Lessons from India for Development. Oxon, p. 19-38.

Kundu A., Sarangi N., Das B.P., Nayyar R., Sharma A.N., 2005. Economic growth, poverty and nonfarm employment: an analysis of rural-urban inter-linkages. In Nayyar R., Sharma A. N (ed.), Rural Transformation in India: The Role of Non-Farm Sector. Institute for Human Development, p. 137-154.

Landy F., 2010. Dictionnaire de l'Inde contemporaine. Armand Colin, Paris.

Landy F., 2008. Nourrir 2,5 milliards de personnes, plus et mieux: les défis de l'Inde et la Chine. In Charvet JP (ed.), Nourrir Les Hommes. SEDES, p. 184-224.

Lehoux H., 2014. Diagnostic agraire. Valsad district, Sud du Gujarat, Inde. Mémoire de fin d'études IRC Montpellier SupAgro.

Lucas C., 2014. Diagnostic agraire du taluka de Petlad : rétrospective, actualité et perspectives d'un bassin d'approvisionnement de la coopérative laitière AMUL. Mémoire de fin d'études IRC Montpellier SupAgro.

Marius-Gnanou K., 2008. Debt bondage, seasonal migration and alternative issues: lessons from Tamil Nadu (India). Autrepart, 46, p. 127-142.

National Dairy Development Board, 2013. Annual Report 2012. Anand.

Nayyar R., Sharma A.N., 2005. Rural transformation in India: the role of non-farm sector. Institute for Human Development.

Patel S.A., 2011. Status of adivasis/indigenous peoples land series, Gujarat. Aakar Books, New Delhi.

Pattnaik I., Shah A., 2013. Gujarat's Agricultural Growth Model: How Sustainable it is? International Journal of Agriculture and Food Science Technology, 4, p. 281-286.

Planning Commission, Government of India, 2014. Report of the expert group to review methodology for measurement of poverty. New Delhi.

Pouchepadass J., 2006. Le monde rural. In Jaffrelot C. (ed.), L'Inde Contemporaine. De L'indépendance À Nos Jours. Fayard, Paris, p. 421-458. 
Ramachandran V.K., Rawal V., Swaminathan M., 2010. Socio-economic surveys of three villages in Andhra Pradesh: A study of agrarian relations. Tulika Books, New Delhi.

Randhawa M.S., 1980. Indian council of agriculture Research. New Delhi.

Rao N., 2006. Land rights, gender equality and household food security: Exploring the conceptual links in the case of India. Food Policy, 31, p. 180-193.

Rawal V., 2006. The Labour Process in Rural Haryana (India): A Field-Report from Two Villages. Journal of Agrarian Change, 6, p. 538-583.

Scholten B.A., 2010. India's White Revolution: Operation Flood, Food Aid and Development. I.B.Tauris, Londres.

Servet J.-M., 2007. Entre protection et surexploitation: l'ambiguïté de la rémunération par avance en Inde. Autrepart, 43, p. 103-119.

Shah A., 2002. Spatial Poverty Traps in Rural India: An Exploratory Analysis of the Nature of the Causes. Journal of Social and Economic Development, 4, p. 123-147.

Shah A., 2005. Poverty and Natural Resources: Understanding the Dynamics in the Context of Dry Land Regions in Western India. CPRC-IIPA Working Paper 25.

Shah C.P., Shah K.C., 1950. Charotar Sarsangrah (Kheda Zilla Mahitigranth) Partie 1, (Gujarati). Charotar Sarvsangrah Trust vati Lokmat Prakashan, Nadiad.

Shah T., 2009. India's Ground Water Irrigation Economy: The Challenge of Balancing Livelihoods and Environment. Quarterly Journal of Central Ground Water Board, Ministry of Water Resources, 24, p. 21-37.

Shah T., Gulati A., Shreedhar G., Jain R.C., 2009. Secret of Gujarat's agrarian miracle after 2000. Economic and Political Weekly, 44, p. 45-55.

Subramanian S., 2011. The poverty line: Getting it wrong again. Economic and Political Weekly, 46, p. 37-42.

Thorat S., Sabharwal N.S., Nayyar R., Sharma A.N., 2005. Rural non-farm employment and scheduled castes: activities, education and poverty inter-linkages. In Nayyar R., Sharma A. N (ed.), Rural Transformation in India: The Role of Non-Farm Sector. Institute for Human Development, p. 175-192.

\section{NOTES}

1. It is important to specify the source of the data used: according to the 2011 census, $31 \%$ of the Indian population is urban as opposed to $41 \%$ according to Geopolis' figures for the same date (Denis et Marius-Gnanou 2011); in the same manner, the definition of the poverty threshold, which differs in rural and urban areas, is strongly debated (Subramanian, 2011)

2. Nonetheless, the sustainability of this growth in the agricultural sector is questioned (Pattnaik and Shah, 2013; Kumar et al., 2014)

3. A taluk is a subdivision of a district

4. From Adi = "original" and vasi = "inhabitant of" (see Hardiman, quoted by Breman, 2007a concerning the usage of this term).

5. We were unable to gain a deeper understanding of the work relations that existed in the past: we do not know the relative importance of these work relations, nor the precise conditions of exchange. In particular, we do not know whether the system of bonded labour the Halpatis were 
subjected to, analysed by Brennan in his work $(1974,2007$ a) based on a study of villages located less than a hundred kilometres away, was also practiced in Dharampur.

6. Since 2005, an amendment to the Hindu Succession Act allows girls to inherit landed property just like their brothers (Agarwal, 2005). However, according to our fieldworks, the division of land between the sons still seems to be the norm in both these taluks. While our article that focuses on inequalities between families does not deal with the inequalities that women within these families suffer, this still remains a structuring fact of rural Indian society that a number of other authors emphasise on the basis of their work (see for example: Agarwal, 1988; Banerjee, 2005; Rao, 2006; Ramachandran et al., 2010).

7. This is mainly well and bore well irrigation (see Shah, 2009)

8. AMUL was the first milk cooperative created in Gujarat in 1946, near Petlad taluk. The model went on to be reproduced and spread to other parts of India through the National Dairy Development Board during Operation Flood, a series of policies implemented between 1970 and 1996. They were partially financed by the resale of food aid milk products (Dorin and Landy, 2002; Scholten, 2010). Today, the Indian milk cooperatives, collect, transform and distribute milk from 15 million producers who generally raise very small herds (an average of less than 2,5 L of milk collected daily per family member, according to the NDDB data, 2013).

9. Sharecropping is a form of agriculture that involves a share of the produce. In the most common arrangement in Petlad, the owner provides the land and the inputs (including access to entrepreneurial services) and the sharecropper the labour (including, when necessary, day labourers whom he hires for the harvest and whom he must pay). Today, at the time of the harvest, depending on the crops, the owner receives $3 / 4$ to $7 / 8$ of the produce, while the rest goes to the sharecropper. Although the sharecroppers have limited autonomy in terms of crop management, their situation is different to that of an employee who is paid with a share of the produce: they organise the work involved in cultivating the crops, they have a certain leeway in the choice of the crops; they generally obtain the right to cultivate fodder along the edges of the plot. All these are advantages that distinguish them from day labourers. Livestock farming that sharecroppers and day labourers engage in is carried out independently of the landowners.

10. The agricultural income calculated takes into account the agricultural produce sold as well as the agricultural production consumed by the farmer, which is a very high proportion in certain categories of farms. This has been estimated at the market price at which the farmers would have to buy the product if they did not produce it themselves. In Petlad, the income calculated for day labourers includes the sale of daily labour to other farms. However, we were not able to estimate the income generated by the Adivasis as agricultural daily labour in Dharampur that involves travel on a daily basis or for several days between the mountain and the plains which is difficult to distinguish from non agricultural daily labour. An estimation of the maximum total income for this social category, cumulating non agricultural and agricultural activities, is provided in the last part of the article.

11. In these graphs the income per worker is compared to 2.5 times the poverty threshold, taking into account the fact that a worker has to provide for 2,5 people within the family.

12. The added value (gross product from which we subtract intermediary consumption) is related to the number of days of work required for its creation for each cropping system (Cochet, 2015).

13. Apart from specific cases of owners renting land from family that has gone abroad, this balance makes up the owners income. The owners do not pay tax in the Indian fiscal system and have no interest to pay (they do not borrow money for cultivation).

14. 15000 euros at the time the study was carried out.

15. Our study does not provide enough elements to be able to fully explore the question, but it seems that they come in groups to Gujarat, recruited by an intermediary, who brings them from their states. This is somewhat reminiscent of the salaried relationships described elsewhere in 
India, concerning work in the brick factories (Guérin et al., 2007) or sugar cane harvesting (Marius-Gnanou, 2008), where salary advances play a major role.

16. The fact of belonging to certain networks probably plays an important role in the access to these non agricultural jobs.

17. These hypotheses allow us to evaluate the maximum contribution of non agricultural activities to the total income of these social categories. It represents respectively $35 \%$ and $43 \%$ for day labourers with a dairy buffalo in Petlad and the rainfed crop farmers in Dharampur. Most often, the day labouring jobs these social categories occupy, respectively 20 days a month and 100 days a year, are not exclusively limited to the non agricultural sector and correspond to some extent to agricultural jobs. We should note that these calculations only concern male members of the working population: the contribution of non agricultural activities to the total income for women (and hence families taken as a whole) in these social categories is lower than these figures as in both the zones, women find it more difficult than men to engage in highly physical non agricultural day labour.

18. We did not heard about it during our interviews.

\section{RÉSUMÉS}

Through a study in two taluks in the State of Gujarat, this article looks at agrarian systems and their relationship with rural poverty, an essential component of "India's spatial divide". Based on in-depth fieldwork, it confirms the extreme poverty that is rampant in the Indian countryside, in a state that nonetheless shows a high growth rate. It reveals how this poverty can be explained by an unequal distribution of land and water, but also of added value that is rooted in social relations of dependency, which have fundamentally changed very little over the course of the last decades. Non-agricultural activities, however important they may be, do nothing to change these inequalities. In the light of this work, the agricultural development policies targeting a redressal of inequalities in rural areas seem more necessary than ever.

INDEX

Keywords : Key words: India; agriculture; agrarian system; poverty; inequality Thèmes : Sur le Champ - Sur le Terrain

\section{AUTEURS}

\section{CLAIRE AUBRON}

Claire Aubron, aubron@supagro.fr, is Associate professor at Montpellier SupAgro, UMR 868 SELMET, Montpellier, France; visiting researcher at the International Livestock Research Institute, New Delhi, India; associated with the Centre for Social Humanities in New Delhi, India. 


\section{HUGO LEHOUX}

Hugo Lehoux, hugo.lehoux@gmail.com, is Former students at IRC Montpellier SupAgro, Master internship at CIRAD, UMR 868 SELMET, Montpellier, France.

\section{CORENTIN LUCAS}

Corentin Lucas, lucas.corentin@free.fr, is Former students at IRC Montpellier SupAgro, Master internship at CIRAD, UMR 868 SELMET, Montpellier, France.. 